\title{
LUOTTAMUS ON SOSIAALI- JA \\ TERVEYSPALVELUIDEN PERUSTA
}

\section{Pääkirjoitus}

\section{of a II S}

Sosiaali- ja terveyspalveluiden näkökulmasta vuosi 2020 on ollut yllätyksiä ja tapahtumia täynnä: kriisiytynyt ja huono hoivan laatu hoivakodeissa, pandemian aiheuttama terveyspalveluiden kuormitus ja välttämätön uudelleenorganisointi sekä vaikutukset sosiaalipalveluiden tarpeeseen ja toimintatapoihin. Nyt terapiapalveluita tarjoavaan yritykseen on kohdentunut tietomurto, jossa tuhansien palvelunkäyttäjien tietoja varastettiin ja levitettiin internetiin. Palvelun tuottajalta sekä asiakkailta on kiristetty rahaa tietojen julkaisematta jättämistä vastaan. Kaikki nämä yhteen vuoteen pakkautuneet tapahtumat voivat muuttaa ihmisten luottamusta palveluihin, niin julkisiin kuin yksityisiin. Luottamus ja epäluottamus ovat ihmisten tapa toimia. Ne eivät ole kenenkään ominaisuuksia. Tarve luottamukselle syntyy epävarmuudesta tietyssä tilanteessa, jolloin toisen osapuolen tuottama pettymys, luottamusaseman väärinkäyttö tai vetäytyminen tilanteesta ovat vahingollisia. Kun ihminen luottaa johonkin, hän asettaa itsensä alttiiksi toisen osapuolen mahdolliselle huonolle kohtelulle tai jopa kaltoinkohtelulle. Tämä on ymmärretty Tanskassa, jossa Kööpenhaminassa on jo vuodesta 2012 ollut meneillään uudistus, jonka tavoitteena on lisätä luottamusta organisaation sisällä ja ulkopuolella (Bentzen 2019).

Sosiaali- ja terveyspalveluihin tukeudutaan yleensä silloin, kun ei olla kaikkein vahvimmillaan: sairaudet, hoivan tarve, turvattomuus, työttömyys, päihteet tai asunnottomuus voivat olla syitä miksi palveluihin turvaudutaan. Tukea ja apua tarvitsevan on luotettava palveluihin, sillä niiden huomaan annetaan jotain, mikä on erityisen tärkeää: oma terveys ja hyvinvointi. Tuen ehtona niin yksityisissä kuin julkisissa palveluissa on se, että asiakas tai potilas antaa hyvinkin yksityiskohtaista tietoa itsestään: menneisyydestään ja nykyisyyden tilanteestaan ja kokemuksistaan. Ammattilaisten käsissä on paljon henkilökohtaista ja tärkeää informaatiota ja sitä on käytettävä vain sellaisiin tarkoituksiin, jotka edistävät asiakkaiden ja potilaiden hyvinvointia ja terveyttä.Vaitiolovelvollisuus, eettisyys ja lainmukaiset sekä luotettavat tiedon hallinnan ja käsittelyn rakenteet ovat välttämättömiä,jotta palveluihin on mahdollista luottaa. Monet tämän numeron tutkimuksista liittyvät ainakin epäsuorasti luottamukseen ja siihen, miten palveluihin voi luottaa: miten asiakkaista puhutaan, heitä arvioidaan ja heihin suhtaudutaan, millaisia vastuista vapautuksen tiloja ja hetkiä palvelut tarjoavat ja millaiset vuorovaikutusta ja osallisuutta edistävät rakenteet tuottavat hyvinvointia. Luottamus on myös tärkeä osa hyvinvointia. 
Tuula-Riitta Välikoski, Tarja Pösö ja Raija Huhtanen tarkastelevat lapsen huostaanottoon liittyviä kuulemistilaisuuksia institutionaalisena vuorovaikutuksena tilanteissa, joissa on tarkoitus selvittää asianosaisten mielipide huostaanottoon ja siihen liittyvään sijaishuoltoon sijoittamiseen. Käy ilmi, että virallisenkin tilaisuuden vuorovaikutus voi sisältää myös läheisyyttä ja välittämistä. Eija Erosen tutkimus vertaisryhmätoimintaan osallistuneiden äitien kokemuksista ryhmästä omana aikana osoittaa, että oma aika merkitsee vaikeissa elämäntilanteissa oleville äideille hengähdystaukoa ja hetkellistä irtaantumista lapsen hoivasta ja arjesta.

Sosiaaliseen kanssakäymiseen liittyy myös Miina Arajärven, Kaarina Mönkkösen, Taru Kekonin ja Timo Toikon tutkimus psykososiaalisesta sosiaalityöstä nuorisopsykiatriassa. Sosiaalityöllä on tällöin kaksoisrooli, joka koostuu nuoren sosiaalisen toimintakyvyn ja perheen kokonaistilanteen arvioimisesta ja palveluverkoston koordinoinnista sekä terapeuttisesta työstä. Hieman laajemman kuvan antaa Mari Kattilakosken ja Niina Rantamäen kehittämä maaseudun paikallisyhteisöjen hyvinvoinnin analyysiin soveltuva käsitteellis-teoreettinen tulkintamalli. Mallissa keskeisiä ovat paikallisuuden muotoutumiseen vaikuttavat tekijät, kokonaisvaltainen näkökulma hyvinvointiin, vuorovaikutusta sekä osallisuutta edistävät rakenteet ja toimintakäytännöt sekä tulevaisuusperspektiivi.

Tässä vuoden viimeisessä numerossa Risto Eräsaari jatkaa keskustelua kaunokirjallisuuden ja sosiaalityön opetuksen välisestä suhteesta. Numerossa on myös kaksi väitöstilaisuuksien lectio praecursoriaan perustuvaa tekstiä, Marjukka Rasan vammaisen vanhemman toimijuudesta ja Anu-Riina Svenlinin tukiperhetoiminnasta. Kirja-arvioita kirjoittivat Mikko Mäntysaari professorin elämäkerrasta, Pälvi Rantala laadullisten menetelmien teoksesta ja Marjo Kuronen sosiaalityön tutkimuksen vuosikirjasta.

Lopuksi haluamme antaa lämpimät kiitokset luotettavalle ja aina niin avuliaalle toimitussihteerinä toimineelle Kati Katajalle tähänastisesta työstä! Tervetuloa Mari Kivistö Januksen toimituskuntaan. Muistutamme myös Sosiaalityön tutkimuksen päivistä 18.-19.2.2021, jotka ovat nyt ensimmäistä kertaa kokonaan verkossa. Lisätietoa päivistä löydät: https://www.lyyti.fi/p/sosiaalityon_tutkimuksen_paivat

\section{Minna Zechner ja Marjo Romakkaniemi}

\section{KiRJallisuUs}

Bentzen, Tina Øllgaard (2019) The birdcage is open, but will the bird fly? How interactional and institutional trust interplay in public organisations. Journal of Trust Research 9 (2), 185-202. https://doi.org/10.1080/21515581.2019.1633337 